HANS SAUER

Munich University

HansSauer@gmx.net

\title{
IN DEFENCE OF LYDGATE: LYDGATE'S USE OF BINOMIALS IN HIS TROY BOOK (PART 2)
}

Keywords: Lydgate, Chaucer, binomials (word-pairs), variation and formulae, learned and popular binomials

\begin{abstract}
Section 9 deals with variation, i.e. words that are used in different combinations, section 10 with the sequence of the elements and possible reasons for the sequence (phonologic, semantic, translational), and section 11 with the relation to Lydgate's Latin source. Section 12 traces Lydgate's relation to Chaucer: It is well known that Lydgate was a Chaucerian, i.e. an admirer and follower of Chaucer, but perhaps not so well known that he also used many binomials which Chaucer had used. Section 13 lists the binomials that can be regarded as formulaic, and section 14 singles out a pair of binomials where the first binomial is apparently learned, while the second states the same fact in more popular terms. Section 15 provides a conclusion, and Appendix I lists all binomials that occur at the beginning of Lydgate's Troy Book. The figure in Appendix II shows the Primum Mobile and the seat of God according to the Medieval world picture (as discussed in section 14).
\end{abstract}

\section{Variation and repetition}

If each of the 180 binomials consisted of entirely different words, then they would comprise 360 different words altogether. But this is not the case. Lydgate uses many words repeatedly, in two (or more) partly different combinations, where one word is the same but the other is different. In the Prologue and the beginning of Book I there are 29 words that occur in two or more partly different binomials. The word that is employed most frequently in partly different binomials is land with four instances (even five, if the trinomial where it also occurs is taken into consideration); 
several words occur in three partly different binomials (to cast, destruction, fresh, king, root). Some words always occupy the same position (first word or second word), whereas others have different positions. Thus, for example, hear, labour and meyne 'group, company' come always first, and destruction comes always second. On the other hand, e.g. advertence, green, king, and might come sometimes first and sometimes second. How far these frequencies and distributions were done on purpose and how far they are accidental would, of course, also have to be checked on a larger amount of material (ideally the entire Troy Book):

- advertence: 'advertence and inspection' (His aduertence and clere inspectioun, I: 671); ' 'wisdom and advertence' (for wisdam \& prudent aduertence, I: 71);

- cast: 'cast and fantasize' (cast and fantasieth, I: 200); 'cast and lay very low' (cast and leide full lowe, I: 642); 'to expel and cast out', lit. 'fordrive and cast' (fordryue and cast, I: 718);

- discreet: 'discreet and sage' (discrete and sage, I: 686); 'discreet and wise' (discrete \& wyse, I: 679);

- destruction: 'ruin and destruction' (the rueyne and distruccioun, Pr.: 224; synonymous); 'siege and destruction' (The sege also and the destruccioun, Pr.: 107; sequence); 'mischief and destruction' (pe grete meschefes and destrucciouns, I: 369; climax);

- fresh: 'fresh and gay' (fresche \& gay, Pr.: 276); 'green and fresh' (grene \& fresche, I: 141); 'lusty and fresh' (pat lusty fresche sesoun, I: 638);

- green: 'green and fresh' (grene and fresche, I: 141); 'green and tender' (inly grene and tender, I: 166);

- heart: 'with heart and whole intent' (with hert and hool entent, I: 561); 'with humble heart and whole intention' (With humble herte and hool intencioun, I: 526);

- king: 'kings and dukes' (of kynges and of dukes, Pr.: 337); 'governor and king' (as gouernour and kyng, I: 7); 'a governor, a noble king, a worthy warrior' (a gouernour / A noble kynge, a worthi weriour, I: 263-264);

- labour: 'labour and business' (her labour and her besynesse, Pr.: 205); 'labour and diligence' (Besy labour and wilful diligence, I: 72);

- land: 'by land or by navy' (by lond or by navie, Pr.: 329); 'land and region' (In many londe and many regioun, I: 462); 'land and sea' (on lond and see, I: 662); 'reign and land' (regne \& lond, I: 1); 'kingdom - land - heritage' (kingdom ... lande ... eritage, I: 178-179);

- leuene 'lightning': 'lightning and wildfire' (leuene \& wylde fire, I: 286); 'tempest and lightning' (With sodeyn tempest and with fery levene, I: 16);

- lusty: 'lusty fresh season' (pat lusty fresche sesounv I: 638); 'so lusty and so new' (so lusty and so newe, I: 380 );

- manhood: 'for his growth and for his manhood' (for his encres / and for his manhood, I: 197); 'of knighthood and manhood' (of kny3thood and manhed, I: 492);

\footnotetext{
1 The following abbreviations are used: Pr. = Prologue; I = Book I.; CT = Canterbury Tales.
} 
'of manhood and of might' (of manhood and of my3t, I: 99; of manhood and of my3te, I: 564); 'manhood and prowess' (of manhood and prowesse, I: 412);

- meyne 'group, company': 'company or expense' (meyne or costage, I: 495); 'company and victuals' (meyne and vitaille, I: 547);

- might: 'force and might' (of verray force and myzt, I: 293); 'with might and cunning' (with myzt \& sleizte, I: 574);

- mind: 'wit and mind' (wit \& mynde, I: 122); 'mind and memory' (both mynde and memorial, I: 113);

- old: 'of old and young' (of old \& zonge, I: 163); 'dry and old' (drye and olde, I: 138);

- pride: 'pride and presumption' (pride and presumpcioun, Pr.: 72); 'surquidry and pride' (Of surquedrye or pride, I: 452);

- root: 'beginning and root' (the gynnyng and rote, Pr.: 328); 'ground and root' (Grunde \& rote, I: 357); 'crop and root' (crop and rote, I: 240);

- sorrow: 'sorrow and sin' (sorowe and synne, I: 240); 'sorrow and woe' (sorwe and wo, I: 248);

- star: 'the pole and the seven stars' (pe pole and pe sterres seuene, I: 476); 'stars and constellation' (sterrys and constellacioun, I: 672);

- tempest: 'tempest and lightning' (With sodeyn tempest and with fery levene, I: 16); 'tempest or wind' (Tempest or wynd, I: 662);

- war: 'war and strife' (were and stryf, Pr.: 18; synonymous); 'war and peace' (were and pees, I: 1; antonymous); 'peace and war' (pes and were, I: 269; antonymous);

- wise (in trinomials): 'wise and discreet and also virtuous' (Wys, \& discrete \& also virtuous, I: 4); 'wise, discreet and sage' (wis, discret, and sagev I: 265);

- wit: 'wit and mind' (wit \& mynde, I: 122); 'wit and reason' (witte \& resoun, I: 144);

- woe: 'woe and great adversity' (wo and gret aduersite, I: 43); 'of woe and all bad luck [mischance]' (of wo and al meschaunce, I: 357); 'sorrow and woe' (sorwe and wo, I: 248);

- young: 'young and desirous' (3onge and desyrous, I: 386); 'young and slender' (3onge and sklender, I: 165).

Three binomials are used twice with an identical sequence of elements:

- behold and see: beholde and se (Pr.: 369); beholde and see (I: 64);

- high and low: hyze and lowe (I: 158); hize and lowe (I: 442);

- pale and wan: pale and wan (Pr.: 132); pale and wan (I: 46).

Three binomials are also used twice, but with a varying order of elements. Some researchers apparently regard binomials with a different sequence of elements as different binomials (e.g. Tyrkkö 2017), but I regard them as variants of the same binomial:

- cheer 'mood' - countenance: 'neither in cheer nor in countenance' (in chere nor in countenaunce, I: 174); 'in countenance and cheer' (in countenaunce and chere, I: 425); 
- day - night: 'day and night' (day and nyzte, I: 655); 'night nor day' (nyzt nor day, I: 473);

- peace - war: 'in peace and war' (In pes and were, I: 269); 'war and peace' (were and pees, I: 1).

In any case this brings us to our next question, namely whether the sequence of elements is of importance.

\section{Sequence of elements}

A considerable amount of research has been devoted to the sequence of the elements in binomials, and possible reasons or factors for that sequence. ${ }^{2}$ Among the important factors are phonological, semantic and translational ones. These explain a number of instances, but unfortunately there are also exceptions and cases that cannot be easily explained.

\subsection{Phonological factors}

There is a tendency for the shorter element to precede the longer one. A few examples (mainly from the Prologue) are: 'craft and cadence' (by crafte \& cadence, Pr.: 362); 'labour and business' (her labour and her besynesse, Pr.: 205); 'pride and presumption' (pride and presumpcioun, Pr.: 72); 'siege and destruction' (The sege also and the destruccioun, Pr.: 107); 'sloth and idleness' (slouthe and ydelnesse, Pr.: 83); 'advertence and inspection' (aduertence and clere inspectioun, I: 671); 'wisdom and advertence' (wisdam \& prudent aduertence, I: 71).

Unfortunately there are also counter-examples, where the longer element precedes the shorter one. For instance: 'contest and strife' (of contek and of strif, Pr.: 21); 'power and might' (the power \& pe my3t, Pr.: 2); 'sovereign and patron' (souereyn and patrown, Pr.: 7); 'behold and see' (ze may beholde and se, Pr.: 369; I: 64). In the binomials with varying sequence often one sequence fulfils the expectation, namely that the shorter element precedes the longer one, but the other sequence thwarts this expectation, i.e. the longer element precedes the shorter one, counter to the expectation, e.g. in 'cast and fantasize' (cast and fantasieth, I: 200) the longer element follows the shorter, but in 'fordrive and cast' (fordryue and cast, I: 718) the longer element precedes the shorter. Of course, we have no recordings of Middle English pronunciation and it has to be reconstructed; one question is, for example, how far the final «-e〉 was still pronounced and how far it had become silent (cf., e.g. werre and stryf, Pr.: 18; welle and spryng, Pr.: 96; pale and wan, Pr.: 132) - in Lydgate's time it was probably usually silent, i.e. war, well, pale were probably monosyllabic. And there are also binomials whose elements are of equal length, e.g. 'honour and glory' (the honour and the glorie, Pr.: 215); 'high and low' (to hyze and lowe, Pr.: 112).

2 See, e.g. Malkiel (1959), Mollin (2014). 


\subsection{Semantic factors}

The more important element comes before the less important one; ${ }^{3}$ e.g. higher social rank or function comes first: 'kings and dukes' (of kynges and of dukes, Pr.: 337); 'sovereign and patron' (souereyn and patrown, Pr.: 7); 'high and low' (to hyze and lowe, Pr.: 112; cf. Pr.: 182). Perhaps here also belongs: 'Latin and French' (As in latyn and in frensche, Pr.: 115; Latin as the older and at least for the church and for scholarship, also as the more important language). But again, there are exceptions, e.g. god follows lord in: 'the mighty lord, the god armipotent' (The myghty lorde, the god armypotent, Pr.: 4). An explanation for the sequence 'day and night' (bothe day and nyzte, I: 655) could be that the day is more important than the night (and that the night is also closer associated with evil), but there is also the opposite sequence 'night nor day' (nyzt nor day, I: 473).

\subsection{Translational factors}

In translated binomials the sequence of the elements in the translation often follows their sequence in the original. But because Lydgate's version is rather free, there are few binomials in Guido's Latin that correspond directly to Lydgate's Middle English, so that often no direct comparison is possible (see section 11 below). Lydgate's 'first moving' (firste meyving, Pr.: 327 ) is a translation of Latin primum mobile.

\subsection{Other factors}

As mentioned in section 8.3.(7) in Part 1, if there is a sequence of events, this is often mirrored in the binomials: 'siege and destruction' (The sege also and the destruccion, Pr.: 107).

Unfortunately, for many binomials there is no easy explanation or obvious reason for the sequence of their elements, e.g. for 'the beginning and the root' (the gynnyng and rote, Pr.: 328; gynnyng is used literally and rote is used metaphorically, but also the longer word precedes the shorter word); 'colour and hue' (of colour and of hewe, Pr.: 254), 'honour and glory' (the honour and the glorie, Pr.: 215).

\section{Relation to source}

As the main source for his Troy Book, Lydgate uses Guido de Columnis' Latin prose text Historia destructionis Troiae (completed 1287). ${ }^{4} \mathrm{He}$ often refers to the author of his source. The Prologue is his own, but from the beginning of Book I he follows Guido's basic story; in many details his rendering is very free, however. Therefore

\footnotetext{
The so-called 'Me first' principle does not sound convincing to me.

4 The name is also given as Guido delle Colonne, but according to F. Bruni in LexM IV, s.v. Guido 11 (G. de Columnis), Guido de Columnis is probably not identical with Guido delle Colonne. On Lydgate's relation to his source, see, e.g. Koch (1936).
} 
it is also often difficult to compare his use of binomials with the binomials in his source, and often there is no or no clear correspondence. This is partly due to the fact that Lydgate transformed a Latin prose text into a Middle English verse text, but partly also to the fact that he inserted many details that were not in his source, including many binomials. Though in this connection I shall confine myself to only a brief sketch, a more detailed investigation later would certainly be useful.

Apparently Lydgate uses more binomials than his Latin source, which conforms to the general impression that the English translators and versifiers were on the whole fonder of binomials than the authors of their sources. ${ }^{5} \mathrm{~A}$ case where he clearly expands a single Latin word into a binomial is: "in regno" (Griffin 1936: 5) - "in the reign and land' (In pe regne \& lond, I: 1).

But there are also a few instances when he does not render a Latin binomial in his English verse re-telling, but simplifies it to one word, and in some cases he even renders a Latin binomial very approximately. Examples where he simplifies a Latin binomial are:

- “renunciauit et cessit” (Griffin 1936: 6) - 'he has resigned' (He hath resigned, I: 119);

- "in iuuentutis flores et iuueniles potentias renouatum" (Griffin 1936: 6) - 'to youth he was restored ... and renewed to his lustiness' (To zouthe he was restored ... And renewed to his lustynesse, I: 1313): flores has been omitted and iuueniles potentias has been condensed into lustynesse.

Examples where he renders a Latin binomial very approximately and with some changes are:

- "Hunc Thesalie primates et nobiles, hunc plebei" (Griffin 1936: 6) - 'to high and low' (to hyze and lowe, I: 158): primates et nobiles has been condensed to hyze, and plebei is rendered by lowe; high and low was apparently a formulaic binomial to refer to all ranks of society; ${ }^{6}$

- "iustus et nobilis" (Griffin 1936: 5) - 'wise and discreet and also virtuous' (Wys \& discrete \& also vertuous, I: 4): the Latin binomial has been expanded into a ME trinomial; the ME words do not really correspond to the Latin ones;

- "custoditum fuisse mirabili cura et studio dei Martis" (Griffin 1936: 7) - 'that was committed ... to the keeping and busy cure of cruel Mars' (That was committed ... / To the kepyng and the besy cure / Of cruel Mars, I: 275-277): mirabili cura et studio has been translated as to the kepyng and the besy cure, but besy 'busy' is not really a translation of mirabilis, and the simple Mars has been expanded to cruel Mars; crueel Mars is also used by Chaucer (Canterbury Tales, "Man of Law's tale": 301);

\footnotetext{
5 See, e.g. Sauer (2018) on the Middle English and Early Modern English translations of Boccaccio's De mulieribus claris, where there are many more binomials in the English versions than in the Latin original.

6 Cf. Schenk (2017).
} 
- "per incantationem tamen figmenta et artes mathamaticas constitutas" (Griffin 1936: 7) - 'kept it by incantations, by sorcery and false illusions' (Made kepe it by incantaciouns, / By sorserye and fals illucions, I: 349-350): incantationes has been taken over literally; figmenta is apparently rendered by fals illucions, and artes mathamaticas by sorserye.

\section{Examples of an expansion are:}

- "medicabili cura et artifiosa uirtute Medeae" (Griffin 1936: 6) - 'for with their herbs and their poisons, subtle workings of confections, also by the artfulness of their instruments' (For with hyr herbes and hir pociouns, / Sotyl wyrchyngees of confecciouns, / By queintyse eke of heir instrumentys, I: 133-135);

- “in apparatu maximo et comitiue multorum" (Griffin 1936: 8) - 'in company and expense' (in meyne or costage, I: 495; meyne 'retainers'; cf. MED, s.v. meine, and $M E D$, s.v. costage 'cost, expense'); 'company and victuals' (meyne and vitaille, I: 547): Lydgate apparently translated the Latin binomial twice, and in a slightly different way, but omitted the adjectives.

A multinomial that Lydgate imitated but also changed is: "Iason nomine, vir fortis et strenuous et iuuenis, nimium speciosus, modestus, largus, affabilis, tractabilis, pius et omni morum uenustate corruscus" (Griffin 1936: 6) - 'his shape and also his fairness, his strength, his beauty and his liveliness, his gentilesse and wise governance - how large he was ...' (his schap and also his fayrnes / His strenthe, his bewte, and is lyflynes, / His gentiles and wyse gounernaunce, / How large he was..., I: 153-156): Guido uses mainly adjectives, which Lydgate has mostly transformed into nouns. Apparently fortis is rendered by stren $(g)$ the, speciosus by his schap and also his fayrnes, largus by large; modestus is perhaps rendered by wyse gouuernaunce; affabilis and pius et omni morum uenustate corruscus are not really rendered.

\section{Relation to Chaucer}

Since Lydgate was an admirer and follower of Chaucer, it does not come as a surprise that he also used some of the binomials that Chaucer did. A cursory check, without claim to completeness, yielded ten binomials common for both Lydgate and Chaucer. Mostly Lydgate and Chaucer have the same sequence, but there are also a few instances where Lydgate has a different sequence (see: 'honour and glory'):

1. 'child and man' (bothe child and man: Chaucer, CT, Knight: 2830);

2. 'free - bonded' (fre - bonde: Chaucer, Troilus and Criseyde: 1.840);

3. 'fresh and gay' (fressh and gay: Chaucer, CT, Monk: Hercules: 2122);

4. 'hate and envy' (to hate and to envye: Chaucer, CT, Parson, De Accidia: 724);

5. 'high and low' (heigh and logh: Chaucer, CT, Man of law: 1142); 
6. 'holt and heath' (holt and heeth: Chaucer, CT, General prologue: 6);

7. 'honour and glory' (Lydgate, Pr.: 215) - 'glory and honour' (Glorie and honour: Chaucer, CT, Monk: Belshazzar: 2211);

8. 'pale and wan' (bothe pale and wan: Chaucer, CT, Miller: 3828);

9. 'rest and quiet' (in reste and in quiete: Lydgate I: 444) - 'quiet and rest' (in quiete and in reste: Chaucer, CT, Franklin: 760);

10. 'war and peace' (were and pees: Lydgate, I: 1) - 'war and no peace' (werre, and nothyng pees: Chaucer, CT, Sir Thopas: 882);

11. 'up and down' (up and doun: Chaucer, CT, Knight: 2599).

A question of investigative interest is how far Lydgate borrowed directly from Chaucer and how far both relied on a common tradition of formulaic binomials, but this question is not always easy to answer. The most striking case is probably holt and heth 'grove and field' (I: 644), in a passage (I: 623 ff.) where Lydgate obviously imitates or emulates the beginning of the General prologue of the Canterbury Tales. Therefore it is likely that he took the binomial holt and heath directly from Chaucer. And again referring to Gustafsson's criticism we may ask: Why should it be bad for Lydgate to use a binomial if it is good when Chaucer uses it?

There are also binomials which Lydgate has in common with other authors, e.g.:

1. chere \& countenance (John Shirley); ${ }^{7}$

2. false \& envious (Nicholas Love). ${ }^{8}$

\section{Formulaic binomials}

The main criterion for formulaic binomials is certainly that they are used frequently, and in several authors and periods of English. A fixed sequence is probably not a decisive criterion, because some of the frequent and formulaic binomials also have a flexible sequence, in our material especially day and night, which Lydgate also uses in the sequence night and day (cf. Berger 1993: 67, 120). The following cases were certainly formulaic, and most of them are still formulaic:

1. Among the nouns:

- - 'crop and root';

- 'day and night' (formulaic since OE; cf. Berger 1993: 67-68);

- 'rest and quiet';

- 'war and peace' (cf. much later the famous novel by Lew Tolstoy).

2. Among the adjectives:

- 'high and low';

- 'hot and dry' (as the standard description of the attributes of fire);

- 'pale and wan' (still used in Sir John Suckling's poem of 1638, "Why so pale and wan fond Lover").

7 John Shirley (died 1456), The Dethe of the Kynge of Scotis.

8 Nicholas Love (died 1424), Myrrour of the Blessed Lyf of Jesu Christ. 
3. Among the adverbs:

- 'by and by';

- 'near or far' (today usually 'far or near');

- 'to and fro'.

Perhaps all the binomials that Lydgate has in common with Chaucer should also be regarded as formulaic.

\section{Learned and popular binomials}

Lydgate was a learned poet and this is also reflected in some of his binomials (cf. 'Parcae and Furies'; 'Dictys and Dares'; 'Polyneikes and Etheokles'). In his Prologue (lines 326-328) Lydgate uses a sequence of two binomials, namely:
Of the story, as men in bokys fynde,
(Pr.: 326)
The firste mevyng and cause original,
(Pr.: 327)
What was the gynnyng and rote in special
(Pr.: 328)
'Of the story, as men find it in books, the first origin [moving] and the original cause, what was the beginning and the origin [root] in particular'

Lydgate here refers to the "original cause" and the beginning of the Trojan War with two binomials. The first ('first moving and cause original') is the more learned phrase, and the second ('beginning and root') is the more popular phrase (although root is here used in a metaphorical sense and not in its literal sense). But Lydgate also uses the first binomial in a transferred sense. Originally 'first moving and cause original' had a different meaning, and there is a long philosophical and astronomical tradition and a chain of loan-translations behind it. Firste mevyng translates Latin primum mobile 'the first source of motion', which in turn apparently goes back to Avicenna's Arabic al-muharrik al-awwal. Ultimately the idea seems to go back to Aristotle, and it was elaborated by Ptolemy. The primum mobile (first mevyng) refers to 'the outermost of the concentric spheres of the heavens, primum mobile' (MED, s.v. mévinge ib). Outside the primum mobile is the Empyreum (Empyrean), the seat of God himself; see, e.g. the world picture implied in Dante's Divina Commedia, which was probably still valid for Lydgate. ${ }^{9}$ Contrary to Gustafsson's judgement (see $\$ 5$ in Part 1 ) the two binomials discussed here do not show "unnecessary repetitions" without any "semantic or psychological reason" behind them; the first binomial has a rich tradition behind it, and the second one explains the first in easier and more popular terms. Chaucer also uses 'first moving' (O firste moevyng!, Canterbury Tales, Man of law: 295), but he does not expand it into a binomial.

9 See the figure given in Appendix II; cf. also the chapter by Gisela Seitschek in Sauer, Seitschek, Teuber (2016), and map 8c (p. 356) in that volume; furthermore Lewis (1964). 


\section{Conclusion}

The present article (in two parts) pursues a twofold aim. The first aim is a look at Lydgate's binomials (more precisely: the binomials at the beginning of his Troy Book) mainly from a linguistic point of view, by analyzing, e.g. their word-classes, their etymologic structure (native words or loan-words), their semantic structure (synonymy, antonymy, complementarity), and their formulaicity. The second aim is to defend Lydgate against unjustified criticism. Admittedly Lydgate is not a second Chaucer, although he is an admirer and follower of Chaucer. Chaucer, however, is such an exceptional figure that no Middle English poet can really match him. Like Chaucer, Lydgate is very fond of rhetoric, and partly he uses the same binomials as Chaucer. If those binomials are good when Chaucer uses them, they cannot be bad when Lydgate uses them. Moreover, Lydgate employs some binomials that became famous through their use by later writers: pale and wan features in the first line of a poem (see above) from 1638 by Sir John Suckling, and some binomials were (and still are) apparently used cross-linguistically: war and peace is not only an antonymous and formulaic binomial used by Lydgate, but also the title of a famous novel by Tolstoj. ${ }^{11}$ At least in one case Lydgate employs a binomial that has a long and rich tradition behind it: 'first moving and cause original' is not, as has been claimed for Lydgate, without any semantic or psychological reason - on the contrary, it encapsulates the medieval world-picture by alluding to the outermost sphere of the heavens, the primum mobile, which it translates into Middle English.

\section{References}

\section{Editions}

Chaucer $=$ Benson L.D. (general ed.). 2008. The Riverside Chaucer. [ $3^{\text {rd }}$ edition, reprinted with a new foreword by Ch. Cannon]. Oxford.

Griffin N. (ed.). 1936. Guido delle Colonne, Historia destructionis Troiae. [= Medieval Academy of America publications 26]. Cambridge (MA).

Guido / Guido de Columnis = Griffin (1936).

\section{Studies and Handbooks}

Berger C. 1993. Altenglische Paarformeln und Ihre Varianten. Frankfurt am Main.

Koch H. 1936. John Lydgates Troy Book. [Doctoral Diss.]. Berlin.

Lewis C.S. 1964. The discarded image: An introduction to Medieval and Renaissance literature. [several reprints]. Cambridge.

10 For helping to bring this article in a publishable shape, my thanks are due to Birgit Schwan; I also thank the anonymous reviewer for a lot of important advice, Ulrich Schweier for important information, and Vera Falck from the geography department of Munich University (LMU) for adapting the figure given in Appendix II.

11 The original title of Tolstoj's novel War and peace is Война и мир [vojna i mir] - I owe this information to my colleague Ulrich Schweier. How far the same or corresponding binomials are used in several languages is, of course, an interesting question, but this would require separate research. A recent publication of binomials in titles of books is Schauer, Lepper (2018). 
LexM = Bautier R.-H., Avella-Widhalm G., Auty R. (eds.). 1977-1999. Lexikon des Mittelalters. Munich, Zurich.

Malkiel Y. 1959. Studies in irreversible binomials. - Lingua 8: 113-160.

MED = Kurath H. et al. 2000. Middle English Dictionary. Ann Arbor. [also available electronically].

Mollin S. 2014. The (ir)reversibility of English binomials. Amsterdam.

Sauer H. 2018. Binomials in the Middle English and Early Modern English versions of Boccaccio's De claris mulieribus. - Connolly M., Radulescu R. (eds.). Editing and interpretation of Middle English texts: Essays in honour of William Marx. Turnhout: 83-105.

Sauer H., Seitschek G., Teuber B. (eds.). 2016. Höhepunkte des mittelalterlichen Erzählens: Heldenlieder, Romane und Novellen in ihrem kulturellen Kontext. Heidelberg.

Schauer H., Lepper M. (eds.). 2018. Titelpaare. Ein philosophisches und literarisches Wörterbuch. Stuttgart, Weimar.

Schenk U. 2017. Binomials in Middle English poetry: Havelok, Ywain and Gawain, The Canterbury Tales". - Kopaczyk J., Sauer H. (eds.). Binomials in the history of English: Fixed and flexible. Cambridge: 125-140.

Tyrkkö J. 2017. Binomials in English novels of the Late Modern period: Fixedness, formulaicity and style. - Kopaczyk J., Sauer H. (eds.). Binomials in the history of English: Fixed and flexible. Cambridge: 296-321.

\section{Appendix I \\ List of Lydgate's binomials in the Prologue and in Book I of his Troy Book}

If the ME words still exist in ModE, they are first given in their ModE form and then in their ME form; if they no longer exist in ModE or if the ModE form is very different from the ME form, they are only given in their ME form and then they are explained.

\section{Binomials}

1.1. Nouns

1.1.1. Nouns (Prologue)

1. beginning and root (the gynnyng and rote, Pr.: 328)

2. bidding - pleasance (My lordes byddyng fully and plesaunce, Pr.: 74)

3. colour and hue (of colour and of hewe, Pr.: 254)

4. contest and strife (of contek and of strif, Pr.: 21)

5. craft and cadence (by crafte \& cadence, Pr.: 362)

6. crop and root (crop and rote, Pr.: 229)

7. death nor age (deth nor age, Pr.: 257)

8. heart - intention (of humble herte and lowe entencioun, Pr.: 381)

9. honour and glory (the honour and the glorie, Pr.: 215)

10. kings and dukes (of kynges and of dukes, Pr.: 337)

11. land or navy (by lond or by navie, Pr.: 329)

12. joy - dainty (Ioye and gret deynte, Pr.: 79)

13. labour and business (her labour and her besynesse, Pr.: 205)

14. lack or price (With lak or prys, Pr.: 188) 
15. Latin and French (As in latyn and in frensche, Pr.: 115)

16. lord - god (The mighty lorde, the god armypotent, Pr.: 4)

17. manners - name (of maneris and of name, Pr.: 100)

18. moving - cause (The firste mevyng and cause original, Pr.: 327)

19. nature and kind (nature and kynde, Pr.: 160)

20. Parcae and furies (parchas and furies infernal, Pr.: 51)

21. power and might (the power \& pe my3t, Pr.: 2)

22. pride and presumption (pride and presumpcioun, Pr.: 72)

23. ruin and destruction (the rueyne and distruccioun, Pr.: 224)

24. ships - victuals (Of her schippes nor of her vitaille, Pr.: 333)

25. siege - destruction (The sege also and the destruccioun, Pr.: 107)

26. singularity and false affection (singulerte and false affeccioun, Pr.: 289)

27. sloth and idleness (slouthe and ydelnesse, Pr.: 83)

28. sovereign and patron (souereyn and patrown, Pr.: 7)

29. war and strife (werre and stryf, Pr.: 18)

30. well and spring (of knyzthood welle \& spryng, Pr.: 96)

Names: Persons, places

31. city - Ilion (Of the cite and noble Yllyoun, Pr.: 342)

32. Dictys and Dares (Dite and Dares, Pr.: 356)

33. Polyneikes and Etheokles (Polynece and Ethiocles, Pr.: 231)

1.1.2. Nouns (Book I)

1. advertence and inspection (His aduertence and clere inspectioun, I: 671)

2. advice and diligence (With gret avis and grete diligence, I: 261)

3. advice and treatable (with al pis avise and tretable, I: 159)

4. azure and gold (with asour \& with golde to peynte, I: 384)

5. branches and boughs (pis braunchis and pise bowis glade, I: 634)

6. breadth and length (in brede and lenthe, I: 484)

7. case - adventure (of caase or aventure, I: 34 )

8. chamber and table (As diligent in chamber and at table, I: 170)

9. charms and enchantments (With hir charmys and enchauntementys, I: 136)

10. cheer - countenance (in chere nor in countenaunce, I: 174); see also: countenance and cheer

11. child or man (As euere was any childe or man, I: 171)

12. circle and constellation (cercle and constellacioun, I: 692)

13. countenance and cheer (in countenaunce and chere, I: 425); see also: cheer and countenance

14. crop and root (crop and rote, I: 240)

15. crown and sceptre (Crovne and septre with al the regalye, I: 118)

16. custom and law (by custom and by lawe, I: 320)

17. day and night (bothe day and nyzte, I: 655); cf. night - day

18. estate royal and diadem (Estate royal and also diademe, I: 120)

19. favour - mead (for fauour ne for mede, I: 339) 
20. force and might (of verray force and my3t, I: 293)

21. foreseeing and discretion (By for-seynge and discrecioun, I: 73)

22. freedom and largess (To manly fredam and to hyze largesse, I: 438)

23. gentilesse and governance (His gentiles and wyse gouernaunce, I: 155)

24. gold and treasure (golde \& gret tresour, I: 347)

25. governor and king (as gouernour and kyng, I: 7)

26. ground and root (Grunde \& rote, I: 357)

27. harness and array (in harneys and array, I: 497)

28. hate and envy (of hate and of envie, I: 190)

29. heart and intent (with hert and hool entent, I: 561)

30. heart and intention (With humble herte and hool intencioun, I: 526)

31. herbs and potions (with hyr herbes and hir pociouns, I: 133)

32. holt and heath (On holt and heth, I: 644)

33. hour and time (eery hour and tyme, I: 203)

34. increase and manhood (for his encres / and for his manhood, I: 197): encres lit. 'increase', can also mean 'growth'; cf. MED, s.v. encrēs

35. keeping and cure (To the kepyng and the besy cure / Of cruel Mars, I: 276-7)

36. knighthood and manhood (of kny3thood and manhed, I: 492)

37. labour and diligence (Besy labour and wilful diligence, I: 72)

38. land and region (In many londe and many regioun, I: 462)

39. land and sea (on lond and see, I: 662)

40. lightning and wildfire (leuene \& wyldefire, I: 286)

41. lords and barony (Of his lordys and his baronye, I: 391)

42. lordship and regalia (the lordschipe and the regallye, I: 6)

43. love and worship (for loue and worschip, I: 552)

44. manhood and might (of manhood and of my3t, I: 99; of manhood and of myzte, I: 564)

45. manhood and prowess (of manhood and prowesse, I: 412)

46. memory and reason (both memorie and resoun, I: 125)

47. meine or cost (meyne or costage, I: 495): meine 'group, company, retainers'; cf. MED, s.v. meinẹ

48. meine and victuals (meyne and vitaille, I: 547): meine 'group, company, retainers'; cf. MED, s.v. meinẹ

49. might and sleight (with myzt \& sleizte, I: 574): sleizte 'strategy, stratagem, slyness, cunning; cf. MED, s.v. sleight

50. mind and memory (both mynde and memorial, I: 113)

51. mischief and destruction (pe grete meschefes and destrucciouns, I: 369)

52. needle and stone (of needle and of stoon, I: 685)

53. night - day (nyzt nor day, I: 473): cf. 'day and night'

54. peace and war (In pes and were, I: 269): see also: 'war and peace'

55. pole and stars (Aboue pe pole and pe sterres seuene, I: 476)

56. prayer and request (my prayer and requeste, I: 493)

57. reign and land (regne \& lond, I: 1): transl. for L 'in regno' (Griffin 1936: 5)

58. rest and quiet (in reste and in quiete, I: 444) 
59. stars and constellation (sterrys and constellacioun, I: 672)

6o. sword and pestilence (With the swerde \& stroke of pestilence, I: 18)

61. tempest and lightning (With sodeyn tempest and with fery levene, I: 16)

62. tempest or wind (Tempest or wynd, I: 662)

63. sceptre and regalia (septre and regalie, I: 505)

64. shape and fairness (his schap and also his fayrnes, I: 153)

65. sorrow and sin (sorowe and synne, I: 240)

66. sorrow and woe (sorwe and wo, I: 248)

67. strength and hardiness (For here [i.e. their] strenthe and grete hardynes, I: 66)

68. support and help (this support and pi sowpoaille, I: 445): sowpoaille 'help, assistance, support'; cf. MED, s.v. suppowaille

69. surquidry and pride (Of surquedrye or pride, I: 452)

70. venom and hate (Ful of venym and of cruel hate, I: 305)

71. war and peace (were and pees, I: 1): see also: 'peace and war'

72. wisdom and advertence (for wisdam \& prudent aduertence, I: 71)

73. wit and mind (wit \& mynde, I: 122)

74. wit and reason (witte \& resoun, I: 144)

75. woe and adversity (his wo and gret aduersite, I: 43)

76. woe and mischance (of wo and al meschaunce, I: 357)

77. worship and gentleness (Vn-to worschip and to gentilnesse, I: 437)

Names

78. Callisto and Arcadius (Calixtone and Archadius, I: 70o): mother and son, who were first turned into bears and then into stars

1.2. Adjectives

1.2.1. Adjectives (Prologue)

1. bitter - sharp (the bitter wyrdys scharpe, Pr.: 50)

2. bright and clear (More bryzt and clere, Pr.: 170)

3. burnt and choleric (brent and coleryk, Pr.: 10)

4. dim and dark (dyn and dirk, Pr.: 6o)

5. dreary - piteous (the drery pitus fate, Pr.: 105)

6. fresh and gay (dites, pat wer so fresche \& gay, Pr.: 276)

7. high and low (to hyze and lowe, Pr.: 112: adjs. used as nouns; of hize or lowe estate, Pr.: 182)

8. hot and dry (hoot and drye, Pr.: 8)

9. manful and virtuous (manful and vertuous, Pr.: 90)

10. new and new (newe and newe assayes, Pr.: 214; new and newe, Pr.: 253)

11. pale and wan (pale and wan, Pr.: 132)

12. quick and nothing faint (quyk \& no thing feynt, Pr.: 255)

1.2.2. Adjectives (Book I)

1. discreet and sage (discrete and sage, I: 686)

2. discreet and wise (discrete and wyse, I: 679) 
3. dreadful and perilous (dredful and perilous, I: 333)

4. dry and old (a zerde that was drye and olde, I: 138)

5. false and envious (false and envious, I: 249)

6. ferocious and dispiteous ( ful fel and dispitous, I: 283)

7. free and bonded (bothe to fre and bonde, I: 316; adjs. used as nouns)

8. glad and fain (glad and feyn, I: 430)

9. green and fresh (grene and fresche, I: 141)

10. green and tender (inly grene and tender, I: 166)

11. high and low (both to hyze and lowe, I: 158: used as nouns and referring to social classes; of hize and lowe estate, I: 442: used as adj.)

12. huge and great (of huge and gret stature, I: 300 )

13. lusty - fresh (pat lusty fresche sesoun, I: 638)

14. lusty and new (so lusty and so newe, I: 380 )

15. noble - royal (oure noble estat rial, I: 455)

16. old and young (of old and 3onge, I: 163): 'everybody'

17. pale and wan (pale and wan, I: 46)

18. rampageous and wild (ramegous and wylde, I: 282)

19. safe and sound (in body safe and sounde, I: 485)

20. strong and superstitious (strong and supersticious, I: 363 ): allit.

21. terrified and confounded (awaped and amaat, I: 48): awaped 'struck with amazement or fear', cf. MED, s.v. awhäped; amaat 'overcome (as with fatigue or surprise)', cf. $M E D$, s.v. amāt

22. wooden and furious (wood and furious, I: 284)

23. young and desirous (was zonge and desyrous, I: 386)

24. young and slender (3onge and sklender, I: 165)

1.3. Verbs

1.3.1. Verbs (Prologue)

1. behold and see (ze may beholde and se, Pr.: 369)

2. enacted and gilded (they enacted and gilte, Pr.: 198)

3. grafted and set (hath ymped in and set, Pr.: 366)

4. read or see (rede or se, Pr.: 379)

5. searched out and sought (cerched out and souzt, Pr.: 163; serched oute and souzt, Pr.: 318)

1.3.2. Verbs (Book I)

1. behold and see (beholde and see, I: 64)

2. bide and last (bide and last, I: 249)

3. blossom and bud (to blosme and budde, I: 140)

4. cast and fantasize (cast and fantasieth, I: 200)

5. close and hide (to close and hide, I: 209)

6. cast - lay low (cast and leide full lowe, I: 642)

7. conceal and close (It was conceled \& closed in secre, I: 225)

8. enchase and void (That it enchaseth \& voideth, I: 432) 
9. enter and assay (entren and assay, I: 342): sequence of events

10. fordrive and cast (fordryue and cast, I: 718)

11. fordulled and dirked (For-dulled wern and dirked so at al, I: 114)

12. hurt and slay (To hurte and sleen, I: 285)

13. lose or win (til he have lost or wonne, I: 344): cf. Shakespeare's Macbeth

14. refresh and disport (Hem to refresche and disporte, I: 721)

15. save and defend (to saue vs and diffende, I: 448)

16. stellified and deified (wern y-stellefied / In the heuene and y-deified, I: 701-702)

17. strip and flay (Out of his skyn he hath hym stripte \& flawe, I: 588)

18. wake or sleep (where I wake or wynke, I: 439): winken 'to close one's eyes, to sleep'; cf. $M E D$, s.v. winken

1.4. Adverbs

1.4.1. Adverbs (Prologue)

1. true and well (write trewe and wel, Pr.: 314)

1.4.2. Adverbs (Bookl)

1. by and by (by and by, I: 161, 569)

2. fair and womanly (So inly fayr and womanly to sene, I: 556)

3. little or nought (Lytel or nouzt, I: 417)

4. more and more (alwey more and more, I: 208)

5. near (nigh) or far (neze or ferre, I: 658)

6. platly and cunning (platly and konnyng, I: 149)

7. to and fro (rooming to and fro, I: 31)

\section{Multinomials}

2.1. Trinomials

2.1.1. Nouns (Prologue)

1. beast, fowl, and tree (best[e], foule, and tree, Pr.: 53)

2. fraud, negligence, or sloth (With-out [e] fraude, necligence, or slowthe, Pr.: 204)

3. laud, honour, excellence (Laude and honour \& excellence of fame, Pr.: 373)

2.1.2. Nouns (Book I)

1. force, might, strength (Offorce, of my3t, of strenthe pereles, I: 554)

2. governor, king, warrior (a gouernour, / A noble kynge, a worthi weriour, I: 263-264)

3. heart, will, thought (with herte, wil, \& pouzt, I: 151)

4. incantations, sorcery, illusions (by incantaciouns, / By sorserye and false illucions, I: 350 )

5. kingdom, land, heritage (The worthi kyngdam and pe riche lande ... / and the eritage, I: 178-179)

6. thunderdent, hail, rain (With thunder dent and with haiel and reyn, I: 22) 
7. worthiness, strength, hardiness (for her worthines, / For her strenthe and grete hardynes, I: 65-66; her 'their')

\subsubsection{Adjectives (Prologue)}

1. ireous, wood, melancholic (Irows and wood and malencolyk, Pr.: 9): 'angry, crazy, and melancholic'

\subsubsection{Adjectives (Book I)}

1. crooked, lame, blind (he was croked, lame, \& blynde, I: 121)

2. marvellous, excellent, victorious (was so merveillous, / So excellent, and so victoryous, I: 565-566)

3. wise, discreet, sage (wis, discret, and sage, I: 265)

4. wise, discreet, virtuous (Wys, \& discrete \& also virtuous, I: 4)

\subsubsection{Verbs (Prologue)}

1. strive or counterplead or make any debate (stryue, / Or counterplete or make any debate, Pr.: 181): pleten 'argue, debate, take legal action'; cf. MED, s.v. plēten

\subsubsection{Verbs (Book I)}

\subsection{More than three constituents (quadrinomials etc.)}

\subsubsection{Nouns (Prologue)}

1. renown, manhood, prowess, knighthood, worthiness, triumphs, victories, conquest, glories (Her hyze renoun, her manhood and prowes / Her kny3thood eke and he worthynes, / Her tryvmphs also and victories, / Her famous conquest and her songe glories, Pr.: 198-202): nine elements

2. strife, war, siege, everything (The stryfe, the were, pe sege and euerydel, Pr.: 248): quadrinomial

\subsubsection{Nouns (Book l)}

1. age, wit, providence, heart, excellence, renown (pin age, pi witte, pi prouidence, / pi knyztly hert, pi manly excellence, / ... and pin hyze renoun, I: 459-461)

2. cheer, port, sign, dalliance (In cher, in port, by signe or daliaunce, I: 409): quadrinomial

3. herbs, poisons, workings, artfulness (For with hyr herbes and hir pociouns, / Sotyl wyrchyngees of confecciouns, / By queintyse eke of heir instrumentys, I: 133-135)

4. shape, fairness, strength, beauty, liveliness, gentility, governance (his schap and also his fayrnes, / His strenthe, his bewte, and his lyflynes, / His gentilles and wyse gouernaunce, I: 155): a quintuplet; could also be interpreted as a sequence of a binomial, a trinomial, and a binomial

5. wisdom, advertence, labour, diligence, foreseeing, discretion (for wisdam \& prudent aduertence, / Besy labour and wilful diligence, / Hy for-seying and discrecioun, I: 71-73): a sextuplet; could also be interpreted as a sequence of three binomials 


\section{Appendix II}

The medieval world picture: planets, angels, and the Primum Mobile

This figure is based on Dante's world picture as expressed in his Divina Commedia, but Lydgate probably also still had the same medieval world picture; see also Lewis (1964). The figure has been taken from https://de.pinterest.com/cwinbot/dante-inferno/. Cf. also map 8a (Karte 8a) in Sauer, Seitschek, Teuber (2016: 356).

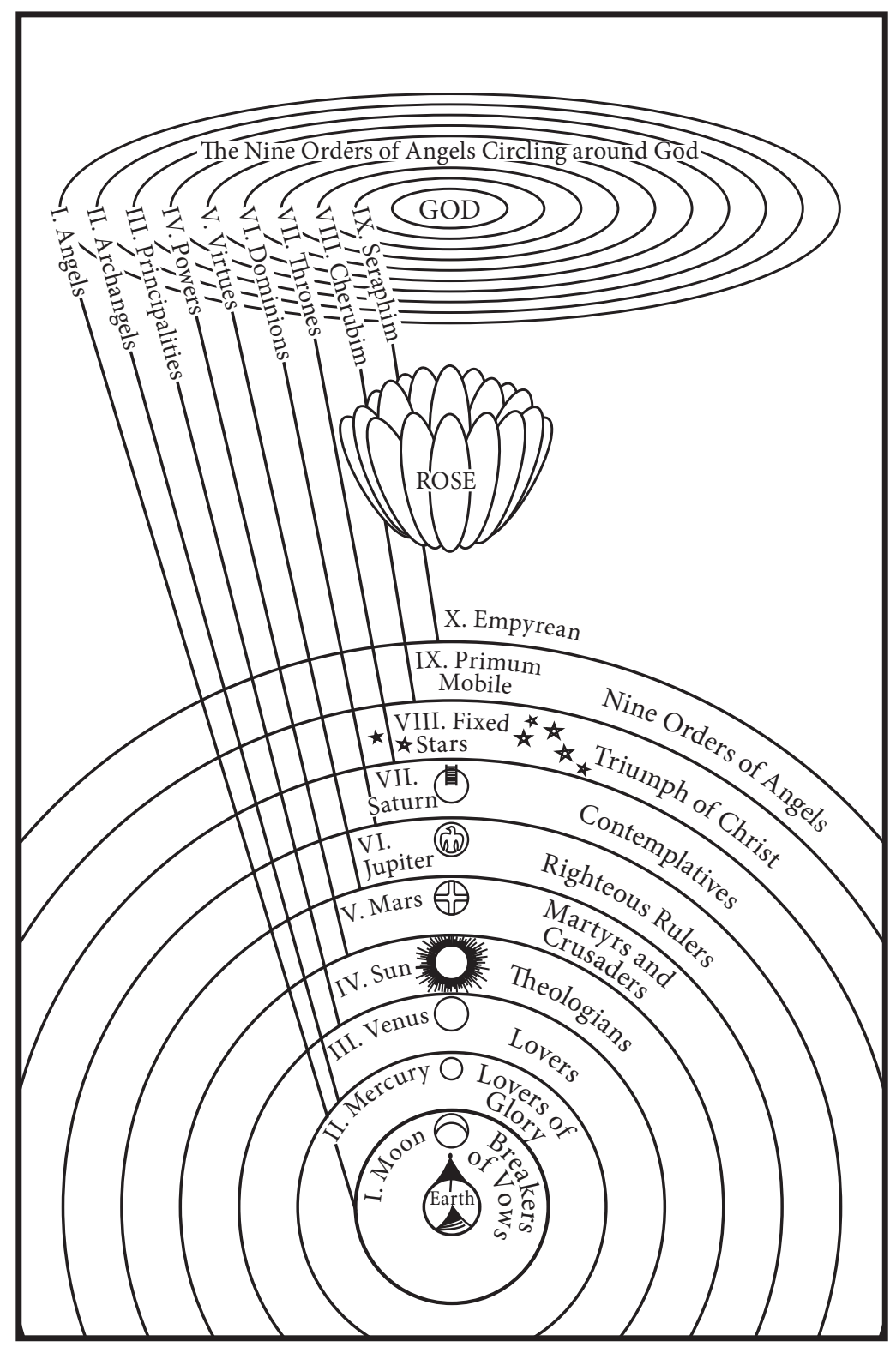

